\title{
Turkey's Otherness in the Identity Discourses of European Parliament
}

\author{
Avrupa Parlamentosu'nun Kimlik Söylemlerinde Türkiye'nin Ötekileştirilmesi \\ Hülya AĞCASULU ${ }^{1}$ \\ Ringo OSSEWAARDE ${ }^{2}$ \\ https://orcid.org/0000-0003-3939-904X \\ https://orcid.org/0000-0003-3449-1074
}

\begin{abstract}
This study aims to analyze discursive constructions of Turkey's otherness and its relation to European identity in the European Parliament (EP). The social constructivist approach is employed in the study and European identity is proposed as a contested, hybrid and relatively exclusivist concept, which is primarily shaped by the self/other nexus particularly in the enlargement process. The focus of the paper is the identification of hegemonic referential strategies and related metaphors emphasizing the otherness of Turkey, without denying the inclusive discourses in the EP. The research data consists of 1999-2012 EP plenary debates. The study's major findings are a) the tendency to present acquired characteristics as the innate differences; b) the majority of exclusive discourses emanate from right-wing MEPs and c) the exclusivist debates peaked during the 200409 term, coinciding with the launch of accession negotiations.
\end{abstract}

Keywords: discourse, identity, European Parliament, enlargement, Turkey, otherness.

Jel Codes: Z1, F5, H83

\section{INTRODUCTION}

Since its origins, the EU has transformed itself due to the need to respond to the present challenges. Contemporary debates on the widening and the deepening of EU includes cultural and identity discourses. Particularly, the fear of cultural distance between Turkish and EU identities is an area of contestation (Melakopides 2000: 300; Rumelili 2011: 235-249). In the literature, studies sought to

\begin{abstract}
ÖZET
Bu çalışma Avrupa Parlamentosu'nda (AP) Avrupa kimliği ile bağlantılı olarak Türkiye'nin ötekileştirilmesinin söylemsel yapılanmalarını analiz etmeyi amaçlamaktadır. Çalışmada inşacı yaklaşım benimsenerek Avrupa kimliği, özellikle genişleme sürecinde öncelikli olarak ben/öteki bağlantısında şekillenen, tartışmaya açık, hibrit yapıda ve nispeten dışlayıcı bir kavram olarak ele alınmaktadır. Çalışmanın odak noktası, AP'deki kapsayıcı söylemleri inkâr etmeden, Türkiye'nin ötekiliğine vurgu yapan hegemonik referans stratejileri ve ilgili metaforları tespit etmektir. Çalışmanın araştırma verisi 1999-2012 yılları arasındaki AP genel tartışmalarından oluşmaktadır. Araştırmanın en önemli bulguları arasında a) kazanılan özelliklerin de içkin farklııklarmış gibi sunma eğilimi; b) dışlayıcı söylemlerin çoğunluğunun sağ-kanat AP üyelerine ait olması ve c) üyelik müzakerelerinin başlangııına denk gelen 2004-09 döneminde dışlayııı söylemlerin en üst seviyeye ulaşmasıdır.
\end{abstract}

Anahtar Kelimeler: söylem, kimlik, Avrupa Parlamentosu, AB genişlemesi, Türkiye, ötekileştirme.

Jel Kodları: Z1, F5, H83 
2008; Aksoy 2012; Matonytè and Morkevičius 2009; Tekin 2010; Canan-Sokullu 2011; Buckingham 2013). In this paper, we seek to contribute to this evolving body of research. The aim of the paper is to uncover processes of othering and reveal how such othering is articulated for Turkey.

In political discourses of the European identity and othering of Turkey, the EP has been a key actor by its heterogeneous character. Its role and legislative power in the EEC and the EU has accelerated over time, to the point that the power of future treaty amendments has come to rest in the EP. It has acted as an influential actor in the making of the enlargement policies, determining who would be in the EU by giving assent to the final terms of accession before the treaty can be signed and ratified (Europarl 2003: 2). In its plenary debates, Turkey had become a topic of debate from 1987 onwards, after Turkey's application for full membership. With the establishment of EU, questions of the European identity and the Turkish identity were raised, with (potential) member states now being identified as something more than strategic partners. For our analysis, the real turning point in the construction of Turkey's otherness in the plenary sessions is the post-Helsinki period, the declaration of Turkey's official candidate status.

Taking into consideration above mentioned remarks, this study seeks to address 'How the otherness of Turkey has been represented in the discourses of European identity in the EP plenary from 1999 onwards?'. We particularly paid attention to the party affiliations of MEPs and formulated two research sub-questions to identify the common referents of the European identity and Turkey's otherness. These are a) what are the hegemonic exclusive discourses of European identity?; b) how Turkey is framed as the other in relation to the European identity? The theoretical basis is structured on the social construction of identity, European 'self' and Turkey 'otherness'. Then the EP plenary contents are analyzed by discourse analytical approach.

It should be noted we do not ignore the existence of inclusive discourses. However our main interest is in Turkey's othering process and how it is expressed in the exclusive discourses. The added-value of our enquiry is the analysis of EP discourses on Turkish identity in contrast to European identity since 1999, when Turkey's candidacy status was officially confirmed. The EP is deliberately chosen since it's the only public forum where directly elected representatives from all
EU member states meet on a constant basis and echo the identity vision of the entire EU (Cuisan 2012: 114).

\section{EVOLUTION OF THE IDENTITY DISCOURSES IN THE EU-TURKEY RELATIONS}

The quest for the Europeanness of Turkey has always been alive in its political and cultural development since the late Ottoman Era. Turkey's relationship with the EU, with its forerunner European Economic Community (EEC), started with the 1963 Ankara Agreement. Until that time the Cold War period had granted to Turkey a golden historical opportunity to gain a European or Western status as a buffer between the Soviet Union and Western Europe. In that period Turkey became a valued pillar of Western security by being member of the Council of Europe in 1949, NATO in 1952 and OECD in 1961. However these progressive developments have not resulted in membership, mainly due to reluctant European partners and political events in Turkey. In the 1960s and 1980s Turkish state experienced two military takeovers. Besides Turkey's Cyprus peace operation in 1974 led to a temporary freeze in relations with the EEC. Then Turkey applied for full EEC membership in 1987 and two years later the EEC found Turkey eligible. Nonetheless EEC insisted on Customs Union Agreement instead of Turkey's full membership due to conjectural developments (Müftüler-Baç 1998, 241-243). Although an agreement was predominantly signed for economic (common market) reasons in 1995, the political logic underlying the agreement dominated over the economic logic from the Turkish side. In the minds of Turkish nations, there was no doubt that Turkey would eventually become a full member of the EU. Only the timing of the EU entry was uncertain and the transitional period would be long and painful (Öniş 1999: 125).

In 1997 Luxembourg Summit, European Council decided to open accession negotiations with eleven applicant countries excluding Turkey. From the Turkish side, the decision concerning Turkey's exclusion among the Central and East European candidates called into question of EU's objectivity (Rumford 2000: 332-335). Because Turkey had a relatively equal or developed market economy when it's compared to the post-socialist states and its political problems were no worse than those many of the other applicants (Öniş 1999: 113). Turkish perceptions of the EU as a closed cultural and religious club were strengthened at that time by the European Council's failure to produce a 
credible explanation for not opening negotiations with Turkey, given that such negotiations do not guarantee EU accession (Müftüler-Baç 2000: 21-22). As a result Turkey's relations with the EU became problematic. However Turkey was officially declared a candidate country destined to join EU in the 1999 Helsinki Summit. This summit affirmed that the accession negotiations could only begin when Turkey would fulfill the Copenhagen criteria that is to comply with the political, economic and administrative standards for the EU membership (Diez 2005: 628). The debates on the desirability of Turkish accession have been intensified during the accession process. As Diez (2004) claims opposition side begun increasingly to base their debates on the grounds that Turkey poses a profound challenge to the European project due to the perceived ambiguities over differences between the European and the Turkish identity (Aydın-Düzgit 2013: 522).

Since the accession negotiations inaugurated, the European identity and Turkey's otherness have been two interconnected and dependent notions in the discourses. In addition it shall be noted that the EU has been regarded by Turkey as the institutional bearer of the European identity during the enlargement process. Indeed the EU has typically been recognized as the only institution with identity enforcement mechanisms and the most visible and powerful actor that shapes the Europeanization process (Müftüler-Baç 2005: 18).

In the Cold War era, Turkey tended to consider Europe as located in the west of the Iron Curtain. Accordingly it seemed like the process of enlargement reached its limits, the boundaries of European integration were thought to be established in the mid-1980s (Öniş 1999: 113). The 1980s involved mutual endorsement of a homogeneous European identity largely based on the West European experiences (Blokker 2008: 258). With the end of the Cold War, Europe's boundaries had shifted from congruence with the line tracing the Iron Curtain to one of civilizational divide defined as cultural difference. Western Europe rushed to embrace its long-estranged Eastern European half and the borders of Europe could now be drawn according to a presumed cultural affinity rather than political expediency (Keyder 2006: 73).

The disappearance of Red Menace, the corresponding negation of the EEC and the creation of the EU, brought into question on Turkey's place in European security arrangements, as a buffer zone between West and Soviet Union. Turkey's value as a security partner for Western Europe had diminished. Instead Turkey's incorporation in the EU would be possible only if the Turkish state would meet European standards. Thus what the Cold War structures enabled Turkey to hide could no longer be concealed. The post-Cold War relationship between the EU and Turkey came to revolve around European values like the rule of law, protection of human rights and upholding democratic principles (Müftüler-Baç 1998: 243-244). Besides European identity became a focal point for analysing European politics including its historical origins and legacies (Müftüler-Baç 2000: 25). At that time Central and Eastern European accession, as well as Turkish candidacy raised deeper concerns about the various dimensions, histories, memories and legacies of European identity. Particularly, Turkey's accession bid called for an ontological inquiry into the nature of EU (Kylstad 2010: 2). EU needed to rethink its cultural borders and political identity in the context of Turkey's candidacy (Baban and Keyman 2008: 109).

EEC had already come to specify characteristics of the European identity. European identity was first introduced in the declarations as an identity policy in 1973 (Stråth 2002: 388). However EU treaties came to reconfigure exclusionary culturalist logics, formulating geographic, spiritual, cultural and secular sources of the European identity in the post-Cold War period (Spohn 2009: 362) According to Maastricht, Copenhagen, Constitutional Treaties two compulsory conditions are observed in the European identity definition. First, the candidate for EU entry should be a European country in terms of geography and culture which is exclusivist and narrow. There was no possible way in which a state could alter its geographic location. Second, the candidates should respect certain European principles and values, and reform its state if it is to be included (Aydın-Düzgit 2013: 525-526; Rumelili 2004: 37-39). In this sense first criterion is based on inherent differences while the latter refers to acquired differences.

The 1992 Maastricht Treaty problematized the European identity as an exclusive and roots-based identity (Art. 128Stat. 2). It was now recognized that the European identity, being indeed a collective identity, could not be divorced from traits like religion, history or culture, and depended on drawing boundaries that separated insiders from the outsiders, us from them and we from the others. The discursive construction of us and them is a basic fundament of discourses of the 
European identity, difference and otherness (Wodak 2001: 73). The Copenhagen summit (1993: 13) explicitly referred to the stability of democratic institutions and respect for human rights as essential preconditions for candidacy status and for opening accession negotiations. The political conditionality of the EU has since become the strongest external factor for political change in countries applying for EU membership and identifying themselves as European (Müftüler-Baç 2005: 18). The 2004 Constitutional Treaty emphasized the European identity as a collective identity' and stated that 'the cultural, religious and humanist inheritance of Europe, from which have developed the universal values ...., freedom, democracy, equality and the rule of law.' (Treaty Establishing a Constitution for Europe 2005: 9). Ambiguities of European identity and Turkey's political stance including ups and downs as stated in this part contributed to the framing of Turkey's otherness and to the differences from European identity in the discourses.

\section{SOCIAL CONSTRUCTION OF IDENTITY}

Theoretically, the study acknowledges the social constructivist approach which assumes that identities are not simply given, but discursively constructed (Diez 2004: 321). Social constructivists often explore the role of social factors, including norms and culture, in constructing collective identities. The emphasis is placed on representations of social situations and political choices. Such constructions come about through dynamic processes of persuasion or social learning (Jupille et al. 2003: 15). Identity construction, in that sense, is an ongoing interactive process that builds upon combination of different ideas on the issue and creates constant change and redefinition process of the ideas (Rubington and Weinberg 2003).

The notion of collective identity focusses on the social rather than individual traits. Identifying a collectivity consists of producing a series of rational arguments, emotional judgments and aesthetic choices for distinguishing that particular collectivity from the others. According to the social constructivists, identity cannot be completely divorced from traits such as ethnicity, religion, history or culture (Rumelili 2008: 99). Collective identity is more or less integrated symbolic structure with time dimensions in which history particularly plays an important role (Schlenker
2013: 28-29). Additionally, collective identity is essentially an exercise of boundary drawing, separating the insiders from the outsiders, 'us' from 'them' and 'we' from the 'others' (YIImaz 2007: 29; Eder 2009: 255-271). The discursive construction of self/other relationship is viewed as the basic fundament of discourses of identity (Wodak 2001: 63-95). Two central operations are necessary for collective identity; an internal definition of in-group, thus certain commonalities to refer to and an external boundary drawing to separate outsiders concentrating on the differences (YIlmaz 2007; Eder 2009). Collective identities are always constituted in relation to difference of others, because a thing can only be known by what it is not (Neumann 1999; Rumelili 2004: 29). Identity is not only constructed by the internal processes, but it is meaningful and more powerful with the definition of others (Hall 1992). The exclusion of others is a powerful driving mechanism and desirable party of the game of identity politics. Besides, in principle, any difference can be politicized and elevated into a marker of identity (Neumann 1999: 1-37).

The differences of self and other identities can be explained by the mirror metaphor. While 'self' constitutes the original object, 'other' occurs as a mirror reflection. Hence what characteristics make self as original are reflected as opposite characteristics of other. The common denominators of collective identity can move along a continuum from the 'thin' to the 'thick' identity constitutions. While thin identity definitions tend to be catch-all phrase that is loose, broader and more inclusive, thick identity definitions are more strict, narrow and exclusive. The self/other relation is also shaped by the inclusive/thin and exclusive/thick nature of the identity which the self claims its relation to the other. Inclusive/thin identities embody differences based on acquired characteristics, whereas exclusive/ thick identities embody differences based on inherent characteristics. If difference is constructed by inherent characteristics, then the possibilities for change in the other non-existent and it is placed in a position of permanent difference. If, on the other hand, difference is constructed by acquired characteristics, then, there is the possibility that the other will become like self one day, so the other is only in a position of temporary difference (Delanty 2002: 345; Neumann 1999; Rumelili 2004; 2008). Besides, depending on magnitude of differences, the location of other can vary from an

\footnotetext{
'Particularly Article 2 states the acquired characteristics of EU and Article 49 states any European country willing to be member should meet these criteria. Further notions referring to collective identity such as "cultural heritage of European significance" or "culture and the history of the European peoples" can be found at Chapter V, Section 3: Culture.
} 
existential threat, inferior, violating universal principles or simply different in the world of self (Diez 2005: 628-629). In EU identity politics, the European identity has been constructed as an original object, while Europe's others emerged as a mirror reflection. That is, what characteristics make the European identity as original are reflected the opposite of Europe's others.

\section{Original Object: Europe as Self}

While the EU opened up the possibility of the construction of a political identity through a less exclusionary practice, geographical and cultural differences have become more important in European identity since the 1990s (Diez 2004). In fact, EU representatives have given mix signals on the identity notion starting from these years. European integration was one of the most crucial developments to re-design identity notion of the Union. In general, enlargement led the confirmation of a monolithic conception of Europe that is culturally and politically defined by Western Europe. One of the outcomes of a singular European identity in the post-Cold War period has been the reconfiguration of exclusionary cultural logics across Europe (Spohn 2009: 362). This selective history and exclusive interpretations enabled a hierarchy of cultures within Europe and strengthened the monolithic view (Arat-Koç 2010: 182-183).

The official documents of Union also contributed to the delivering mix signals, while emphasizing rather a monolithic model. Hence it can be claimed that contemporary European identity definition possesses a hybrid nature but at the same time it is relatively more exclusive and thick identity definitions in the documents. According to Copenhagen criteria, Maastricht Treaty and Constitutional Treaty, two compulsory conditions are observed in the European identity definition. First, candidate should be a 'European' country in terms of geography which is exclusivist and narrow. There is no possible way in which a state can alter its geographic location. This compulsory situation is in line with the enlargement ideas and identity constructions of 1990s. Second it should respect certain inclusive and broad principles only if it can reform itself (Neumann 1999; Rumelili 2004). While the first criterion is based on inherent differences, the latter refers to acquired differences.

Along with the official documents, the academic and elite debates feed from both inclusive and exclusive perspectives reflecting their ideologies. Since the study stands on the elaboration of the exclusive identity construction, the hegemonic discourses of European identity's roots shall be explained in order to answer the first sub-question 'what are the hegemonic exclusive discourses of European identity?'. Exclusive European identity formation possesses a number of powerful in-group referents that is ideologically and historically grounded as the basis of differentiation. Although the substance of European culture is contested, its origins consist of values opposing the values of other cultures. Distinguishing a European culture from others is a strategy for the construction of a European self (Eder 2009: 436). European heritage, related with the idea of Europe, is based on a specific set of thick cultural values (Blokker 2008: 263) including Greco-Roman civilization, Christianity, French Revolution and the ideas of the Enlightenment which serve as the core elements of the European heritage. By this legacy, European identity necessarily contains a demarcation from the non-European (Stråth 2002: 388-397). The nature of listed traits is in fact acquired characteristics that can be obtained by the certain developments of a country. However the emphasis of the legacy is the 'history' that claims original ownership leading to re-categorization of them as innate traits. For instance, democracy as one of the defining elements of European identity is seen as preserved throughout the ages, from ancient Greece to contemporary Europe (Aydın-Düzgit 2013: 537).

Additionally, the religion is the hegemonic referent in European identity. Christianity and common Christian heritage serves as an identity marker. Christianity is understood not only as a belief system but also a civilizational idea, a political culture and a lifestyle. Weiler (2007: 143) defends recognizing Christian historical and cultural identity in the symbolism of the preamble of European Constitution due to its universal ethical and moral values that even the others can respect. According to him, the reconstruction of the European integration history from a Christian standpoint is needed. It is believed that the cultural roots of secular European values, such as the separation of spiritual and worldly affairs, the separation between the public and the private spheres, the idea of natural rights protecting the individual against the state, and the culture of capitalism, all have their roots in Europe's Christian heritage. Regardless the degree of attachment, this perception indeed ascribes an inherent characteristic and assumes that others who do not share the Christian heritage, would not acquire European values and integrated into European societies (YIImaz 2007: 298-299). 
Geography, as a mode differentiation, is another hegemonic exclusionary device and also a fuzzy concept regarding identity definitions in the popular political culture of Europe. Not only the post-Cold War era, but also history has contributed to geographical and physical boundary construction. In Ancient Greece, geography was used as a differentiation particularly from Asian civilization. In $18^{\text {th }}$ century, the eastern border and a division from Russian civilization became prominent. Intellectuals of that time considered Urals as the natural dividing line between Asia and Europe, physically, economically and civilizational sense (Mikkeli 1998: 163-164). Again since the 1990s, the relations of identity politics and geography heightened and linked with each other in European identity formation through practices of othering (Diez 2004: 331; Murphy 2007: 586). Europe has gathered a huge history of images of its boundaries that are used selectively to define its borders. These constructions used as objective referents and put them together into a meaningful whole, i.e. into an identity (Eder 2006: 256).

In the exclusionary identity formations of Europe, the above stated modes of differentiations are presented as an original object, while others are mirror reflections. Addressing the second sub-question, the otherness of Turkey is framed by historical, cultural, political, religious and geographic dominant referents of out-group. They are based on inherent differences except for political difference which, to some extent, are based on acquired traits considering Copenhagen criteria. However, there is the tendency in discourses that political otherness fall into the inherent difference category due to historical evolutions of Europe as mentioned above.

\section{Mirror Reflection: Turkey as Other}

Discourses on the European identity in relation to the question of Turkish accession have divided elites, voicing conflicting responses to Turkey's full membership. It shall be admitted that there are many proponents of Turkey's membership. At the same time, it can also be claimed that the opposition discourses against Turkey's membership are predominant, not only in terms of meeting the objective criteria to become member, but also inherent and acquired differences. In the discourses, EU countries are geographically continental Europe, demographically in medium or small sizes, Christian, developed, civilized and constitutional. On the other hand, Turkey is constructed as mirror reflection with differences like, large, Asian or at least periphery to continental Europe, Muslim, military tradition of state, developing and modernizing. All these contrasts constitute background of Turkey's identity discourses.

Addressing the second sub-question that is "the framing of Turkey's otherness" possesses referents that the exclusive discourses reason themselves. In general these framings are historical, religious and geographical. Most of the discourses on Turkish civilizational compatibility base their arguments on the differences of historical evolutions. Historically, discourses against Turkey have two assumptions emphasizing inherent differences. The first one is that European legacy represents a progression from Ancient Greece to the Enlightenment and is the product of this linear history. The second assumption is that homogeneous European culture and its values are culturally and essentially internal to its participants. In this sense historical European heritage cannot be attributed Turkish identity. Discourses on different historical developments involve references to Turkey's inability to become democratic and respect to human rights, since Turkish secularism was assumed as artificial and adopted only by a small group of Westernized Turkish elites and protected from that society only by the force of arms. Consequently, what makes European secularism is not found in its implementation but rather in its shared common European heritage (Yılmaz 2007: 300; Baban and Keyman 2008: 117).

Another dominant referent is based on Turkey's religious traits. Historically, the representation of Islam as the other of Christian Europe has not been positive. As observed by many scholars, Islam for centuries and Islamophobia nowadays framed as threat to Europe and Christianity (Canan-Sokullu 2011: 483-497; Yılmaz 2007: 300). In hegemonic debates, this clash appears that elites can reason their discourses against Turkey's membership (Rumford 2000: 337). What is more interesting is that, democracy, rule of law, constitutionality and secularism are the acquired differences that might be attained by candidate countries. However, the exclusive discourses tend to categorize them as inherent traits and to root them in the historical dimension of European identity.

Turkey's geography is another differential framing. Turkey, possessing lands both in Europe and Asia, is also seen as 'a bridge between Europe and Asia, but not as a European country' (Yanık 2009: 531-545). According to Diez (2009: 328), although the line dividing Europe and Asia has traditionally been drawn through 
Turkey, historically Asia Minor is not really part of Asia either. Hence, it is a social reality that contemporary Turkey is different from EU countries due to inherent and acquired characteristics. However, it also depends on the European identity definitions as being thick/ exclusive or thin/inclusive and the hybrid nature of entry criteria.

\section{DISCOURSE ANALYSIS OF EP PLENARY SESSIONS}

A discourse is defined as 'shared set of capabilities enabling the assemblage of words, phrases, and sentences into meaningful texts intelligible to readers or listeners' (Dryzek 1988: 710). It is institutionalized way of thinking channeled through language which has certain structure, logic appealing to certain proponents of a specific topic. Rather than being a bare language, discourse is an influential tool and powerful strategy depending on its persuasiveness and logical construction to mobilize people. Discourse analysis assumes that all actions and practices are socially meaningful and the meanings are shaped by social and political struggles in specific historical periods. In this sense, it aims to show how the actions and practices are realized and what they mean for specific social entity (Wetherell et al. 2001). Another dimension to mention is the interrelation of discourse and hegemony. It is an activity in a power struggle rooted to the basic social structures and ideological practices. Hence, discursive political activity contributes to construction of power relations and political domination (Phillips and Hardy 2002).

The study particularly suits to discourse analysis since it deals with the 'social construction' of identity and otherness notions by MEPs. The study's unit of analysis is the plenary debates of the EP. In identity politics, EP has been a key actor by its diverse views. Its role and legislative power in the EEC and the EU have accelerated over time, to the point that the power of future treaty amendments has come to rest in the EP (European Communities 2009). Then EP became an influential actor in the making of the enlargement policies, determining who would be defined in the ingroup by giving assent to the final terms of accession before the treaty can be signed and ratified. It also had a leading role on Turkey's accession, such as suggesting suspension of negotiations after the customs union agreement due to violation of democracy and human rights (Europarl 2003: 2). Although it is not explicitly stated in any documents, Turkey is assumed to be a topic of debate agenda from 1987 onwards, i.e. after Turkey's application for full membership. For the study the real turning point in the EP's plenary sessions is the post-Helsinki period, the declaration of Turkey's official candidate status. Discourses of MEPs are particularly important regarding identity politics, since it gathers all nationalities and ideological perspectives. In that sense MEPs are channeling their positions and mental constructions through languages and texts. From a social constructivist viewpoint, they play an important role in framing of collective identities since they are continuously constructed, negotiated and contested.

A number of steps are employed to analyze EP plenary debates. In order to detect related plenary debates the study utilized quantitative content search. Then the detected excerpts are qualitatively assessed by discourse analysis. In the analysis, the first step is the lexical search, content assessment and the classification of discourses. The data for the study are collected from the accessible online plenary debates by lexically searching the word 'Turkey'. We have collected and analyzed 1244 debates which 'Turkey' passed. Further relevant passages investigated whether they are exclusionary discourses. The'neutral' debates mentioning facts and technical matters, also thin/inclusive European identity discourses are sorted out to clarify exclusive discourses. Before the analysis part, we shall also note that discursive construction regarding Turkey was not only confined to the topic of enlargement or identity issue. Freedom of religion, freedom of expression, Kurdish minority rights, women's rights, so-called Armenian genocide, Cyprus issue, demography, population, immigration and budget topics (c.f. Akçay and Yılmaz 2012) are recurred in the discourses.

We detected 258 out of 1244 EP plenary debates possessing explicit exclusivist statements. The distribution of exclusive discourses are 47 out of 380 (ca $12 \%$ ) in 1999-2004; 139 out of 533 (ca 26\%) in 2004-09; and 76 out of 327 (ca 23\%) in 2009-122. The content assessment of the EP plenary revealed in total above $20 \%$ of the debates, meaning on average one out of five speeches, bear the exclusivist expressions regarding Turkey.

The preliminary content research revealed the presentation of otherness hit peak in the second term, coinciding with the time of the launch of ne-

${ }^{2}$ The online data gathered for the study was accessible till 2012 at the time of research. 
gotiations with Turkey. Since 1999, Europeanization process and the related domestic political reforms have been stimulated by EU in an increasing fashion in the Turkish side (Müftüler-Baç 2005: 6-30). The incentive to adopt major political changes can be seen rapprochement of acquired differences. Paradoxically the volume of exclusionary discourses has increased, despite the reform improvements in Turkish domestic politics at that time. This controversy might possess multiple meanings. The immediate thought might be undermining the attempts to fulfil the gap of acquired differences by the country and the tendency to show them as innate differences. The second can be Turkey's progress to membership becomes a reality to take into consideration in the eyes of elites. So the fear of integration was also a key for the increasing opposition.

The analysis' second step included the further elaboration on the members' political affiliations. The purpose to seek for MEPs political standings is to avoid treating EP as homogenous entity. It is found that there are exclusive excerpts belonging to the left-wing representatives with a very low percentage (ca 10\%) when compared with the right wing MEPs. On the other hand, nearly $90 \%$ of the exclusivist arguments focusing on the inherent features belong to a range of center-right and far-right MEPs. The findings were not surprising, since general perception was that the right-wing values are grounded on the more conservative and traditional inherent traits, while left-wing ideology attaches more importance to the acquired characteristics. It can be claimed that the high ratio among right-wing is also an affirmation of the negative predication of Turkey's otherness mostly relying on the inherent differences.

The last step is the main analysis of the study focusing on the discourse strategies based on identity membership. The paper sought to find out hegemonic referential strategies and the metaphors concretizing differences of in-group and out-group. Hegemonic referents and metaphors falling into identity membership include positive in-group European identity (real object) and negative out-group Turkish representation (mirror reflection). The metaphors employed in debates are aimed to steer attention, conceptualize issues and create a common-sense meaning (c.f. van Teeffelen, 1994). They assist the capturing of an abstract experience by picturing it something concrete and familiar. They are also utilized to draw borders between self and other.
Referential strategies are the most encountered exclusivist discourse topic. Group demarcations are usually driven by the social processes of categorization, comparison, competition and conflict. These dynamics reinforce the biases towards homogeneity of in-group, and the out-group members are framed by stereotyping and hostility (Scheuer and Schmitt 2009: 554-555). While asserting the non-Europeanness, the discourses also picture Turkey in different magnitudes ranging from simple stranger to existential threat to the collective identity of Europe. The following excerpts are some striking selected samples of hegemonic referents:

(1) '... nor is it part of European history, whose religious, cultural and political landscapes have been defined by Christianity, the Renaissance, the Enlightenment and the democratic nation state.'van Dalen, November 25, 2009.

(2) 'When de Gaulle built Europe with the other Europeans, he said that Europe was determined by her geography, her Greco-Roman culture and the Christian religion. So now we are going to bring the Turks into Europe. That will be a crime for Europe. Do not commit it.' Karatzaferis, December 13, 2004.

(3) 'Mr Chirac, ..., recently said that we are all children of Byzantium. It is hard to think of a more sinister omen, since the children of Byzantium, busy discussing the sex of angels with their parents and their councillors were overwhelmed by the Islamic army of Sultan Mehmet II on 29 May 1453 after a month-and-a-half-long siege. In a symbolic and barbaric gesture, the Sultan dipped his hand in the blood of the dead Christians and daubed this blood on the wall of the Hagia Sophia in Constantinople, which became and has remained Istanbul's main mosque.'Le Pen, Jean-Marie, November 18, 2004.

These excerpts connect powerful referents constituting the European heritage. The European identity is associated with a number of in-group features that is ideologically and historically grounded as the basis of differentiation. In these discourses, culture and religion go hand in hand to identify referents such as history and civilization. Despite the witnessed diversity, division and conflict of European history (Scheuer and Schmitt 2009: 553), the in-group identifies itself with a monolithic linear historical development as stated in 
terms of Renaissance, Enlightenment, Ancient Greece, Greco-Roman culture $(1,2)$.

Undeniably, Christianity is presented as both religion (2) and political and cultural life (1) that is a component of the European legacy. It is understood as not only a belief system but also a civilizational idea, political culture and lifestyle that can be termed as 'Christian Europe'. It is believed that the cultural origins of secular European values have their roots in the Christian heritage (YIlmaz 2007: 298). While Christianity is an innate collective trait, Turkey belongs to the out-group. In the excerpts, the instrumental construction of in-group similarities is created through selective use of pronouns 'we', 'us' and 'together' that define the collective identity. Besides, excerpt (2) uses blaming strategy against oppositional discourses that are being delegitimized. Turkey is not only depicted different but also a threatening entity to the point that its accession would mean a 'crime'.

Another demarcating feature is that whereas belonging to the in-group is presented positive connotations and hierarchal superiority, Turkish otherness is identified negative connotations and cultural inferiority vis-à-vis Europe. The excerpts (1) and (2) selectively use the good historical developments and presents Europe as a homogenous entity. While Europe is built on a higher civilization, the image of Turkey is represented barbaric (3) with a historical 'clash of civilization' manifested by the conquest of Constantinople. The rhetorical use of the word 'Constantinople' belonging to Christian European history contrasts with the name of 'Istanbul'. The city's name change in the paragraph emphasizes the transformation to another civilization. Besides the historical portrait of Ottoman Sultan is a strategy employed to revitalize older images of Turkey's otherness. It reveals the previous Turk/Ottoman vision which is still alive in the collective imaginary of Europe. It is also an interesting strategy that Europe's Byzantine legacy is explicitly downgraded in the in-group traits, since proponents of Turkey use the inclusion of this civilization in the European heritage (c.f. Delanty 1995; 2002) which would imply potential possibility of Turkey's integration to in-group.

Geography is one of the most frequently used hegemonic referent in the discourses of MEPs. The discourses make use of geography as objective and politically correct criticism, to emphasize otherness. Geography serves as the easiest and most secure denominator accompanied by the questioning of
European borders and the potential danger of terror and instability in the Middle East.

(4) 'Turkey is not Europe, given that $97 \%$ of Turkish territory is in Asia.' Allam, March 28, 2012.

(5) ' ... having been given no geographical boundary, this Europe, after having let in Turkey, will have no grounds to refuse the entry of other Asian or African countries.' Lang, December 13, 2006.

(6) 'The fact is that, under Article 49 of the Treaty on European Union, any applicant for membership of the European Union must be a European State. Turkey is an Eastern power; it plays a dominant role among the Turkish-speaking peoples of Central Asia and shares lengthy borders with Iran, Iraq and Syria. Such an unstable region, in our view, is no place for the European Union.' Mathieu, April 1, 2004.

In the refined EP discourses, geography is used as the 'objective science' that is assumed to be no one can be opposed to. Giving the statistical proportions of the country's landscapes (4), the discourses assert the geography, per se, is seen sufficient to accept otherness. The speaker acknowledges geography as an objective truth. On the contrary, geography and borders are constructed primarily by human decisions based on historical and political contingencies (Tekin 2010:114-115).

Connecting geography with boundaries, the borders of Europe are clearly defined in the selected debates, while excluding the people beyond the borders. This unambiguous vision of Europe's borders is presented in the excerpt (5) exaggerate the consequences of Turkey's membership. In the excerpt (6), it is located in the region of terror, instability, border problems, and ongoing wars. It also stresses the differences regarding the geo-political role. While the $\mathrm{EU}$ is a European and Western organization as stated in an official document, Turkey is geopolitically presented an Eastern country, close to the Central Asia and Middle East, proving the belonging to another in-group.

The selected paragraphs refer to constructed inherent differences that Turkey cannot possibly alter. Discourses also manifest constructions of acquired differences which the country might attain mainly stemming from Copenhagen criteria. However, these differences are also announced as the sources of inherent otherness: 
(7) '...Turkey is not a European country and that our western democratic model is not necessarily shared by a nation whose heritage has other sources.' Le Pen, Marine, July 6, 2005.

(8) 'There is not an Islamic country in the world that meets the Copenhagen criteria, and Turkey is hardly likely to do so either ...' Camre, April 1, 2004.

(9) 'Although it is a secular state, culture and history are very different from the current EU Member States, which bear the stamp of Christianity.' Belder, November 19, 2002.

While referring to the lack of democracy, above statements present democracy as a homogenous and innate trait. Turkey's democratic deficits allegedly stem from the inherent historical traditions of the society and more generally from the world of Islam. Turkish democracy is a kind of deviant form which political and cultural deficiencies prevail, and does not comply with the European standards $(8,9)$. Thus it is implied that democracy alone is a Western term which can only be properly performed by the West without leaving a room for alternative definitions (7). Turkey also belongs to in-group of Islamic countries (8) religiously stressing the differences between self and other. The referent of European history and religion, as a way of political life, go hand in hand in the discourses.

A particular form of referential strategies is the metaphors. They are interesting pieces of identity memberships, since they contribute to the self and other demarcation. Metaphors encountered can be classified as 'container' and 'personification metaphors'. All the container metaphors indeed serve to the concretization of in-group and out-group demarcation. Besides, the most frequently used 'personification metaphors' are family, marriage, house and child.

(10) ' (Turkey) represents a potential Trojan horse of radical Islamism in our continent.' Bizzotto, September 27, 2011.

(11) 'Turkey is closer than ever to our gates.' Le Rachinel, September 27, 2006.

(12) 'We are against arranged marriages: to get married you have to know each other and love each other, and that applies to Turkey's ambitious goal...' Pistelli, September 26, 2006.

(13) 'Europe has moved too far in Turkey's direction, despite the latter behaving like a spoilt child blackmailing its parents?' Zaleski, September 28, 2005.

(14) 'Turkey is an adopted child, and we should not forget that the responsibilities of the family and of the parents are particularly challenging when adopting a child. I hope we are all fully aware of this, and that we will begin to put our European house in order.' Jałowiecki, December 15,2004

The metaphors used tell a lot about the members' visualizations and how they place Turkey in their mental maps. Container metaphors as 'gate' and 'door' are meant to visualize the spatiality of demarcation of self from the other. The excerpt (11) gives the message that the inmates of Europe control the door for Turkey. They symbolize the outsider status of Turkey, passively 'waiting in the gates of Europe' and possessing a potential threat to collective identity. The Trojan horse (10) metaphor deeply reveals the concerns regarding the danger of Turkey as a bearer of Islamic fundamentalism. It is also perceived that Turkey has a kind of 'sneaky plan' to damage Europe. It promotes the existing fears of religious terror by picturing a dangerous country. Turkey is seen the source of Islamic terror and contributes to the intrusion of political Islam into the European continent. In the discourse, the other religion is equated with the insecurities while conceptualizing monolithic defining feature of out-group.

Personification metaphors of 'house' and 'family' serve the same purpose. While belonging to the house and family represents the ownership of the in-group, the outsiders are the strangers. They symbolize homogenous, familiar, secure and united entity bounded with shared common heritage. 'European family of nations' symbolizes the innate descent of Europeanness that one can either be family member or not at all. The marriage metaphor is commonly goes hand in hand with the family metaphor. Any relation can only be constructed by 'marriage' founded by 'contract' between the EU and Turkey. The marriage metaphor has additional meanings emphasizing differences on the religion, culture and civilization between the spouses, a marriage between two distinct worlds with a necessary non-blood tie. In the excerpt (12), the marriage is doomed to be 'an arranged marriage', not 'a love marriage.' The bottom line, EU has to deal with domestic problems of Turkey as a result of the forced marriage. Apart from the marriage metaphors, Turkey can be included as either a spoiled or adopted child 
in the 'European family' $(13,14)$. A spoiled child is irresponsible and problematic, needed to be disciplined in the European house by mature members. To sum up, exclusive referential strategies i.e. membership categorizations and metaphors are assumed to be derived from inherent traits. However acquired traits are also perceived as if inherent trait that cannot change.

\section{CONCLUSION}

While modernization is equated with Westernization and being a member of the EU on the Turkish history, identity politics has been a legitimacy issue on the EU side. For Turkey, Helsinki Summit was the opportunity to change discourses of elite project into a rational 'normalization process' to reform domestic structure and contribute to the civil content. For EU, ratification of the Constitutional Treaty was the opportunity to create an EU identity based on acquired traits and post-national citizenship. Although the opportunities for another vision of identity are not missed, there is a long way to change exclusive 'meaning-making' into an inclusive one.

It would not be unfair to state that both EU's and Turkey's contemporary situations are at the center of the storm. One of the study's critics might be the data until 2012, since EP's plenary sessions were publicly accessible till that time at the time of research. But the recent developments on the EP's composition revealed more radicalization of the MEPs specifically following the 2014 elections. Even there has been a record in the xenophobic populism alongside with the rise of anti-EU rhetoric of Eurosceptic representatives (Brack 2015; Grabbe and Groot 2014). This means exclusive identity discourses and otherness of Turkey may be voiced more than ever which can be subject for further studies.

The existence of self-other notion concerning the EU identity politics specifically uncovering Turkey's otherness and its repercussions are re-affirmed by the research. Without ignoring the inclusive approaches and EP's diverse composition, the exclusive identity discourses are assessed. The original contribution of the study is the investigation of EP which is the key platform of representing all EU nationals and political groups. The substantial data extracted from online EP plenary debates in order to give the 'picture' of EU countries on Turkey's otherness. It is observed that the exclusive views belong to the right-wing. Acquired differences stemming from Copenhagen criteria such as democracy and secularism are also presented as inherent differences. Additionally, the density of exclusive discourses increased in the second term, since the launch of the negotiations. As a specific mode of referential strategy metaphors are employed to concretize the case of Turkey, stressing exclusivist standpoints.

The study acknowledges the multiple factors that affect Turkey's current situation along with the fact that identity concerns influencing EU-Turkey relations. The challenges originating from the differences are controversial issue which seems to be a heated future discourse agenda affecting enlargement policies. It can be claimed that Turkey issue is one of the fundamental points in the evolution of European identity and vice versa. Yet, any decision about Turkey will have repercussions on the meaning-making of self/other reproductions. 


\section{REFERENCES}

Akçay, Belgin, and Bahri Yılmaz (2012). Turkey's Accession to the European Union: Political and Economic Challenges. UK: Lexington Books.

Aksoy, Sevilay Z. (2012). "The prospect of Turkey's EU membership as represented in the British newspapers The Times and The Guardian, 2002-2005". Journal of European Studies 39,4: 469-506.

Allam, Magdi Cristiano. "Enlargement report for Turkey". http://www.europarl.europa.eu. (Accessed 12.09.2016).

Arat-Koç, Sedef (2010). "Contesting or affirming 'Europe'? European enlargement, aspirations for 'Europeanness' and new identities in the margins of Europe". Journal of Contemporary European Studies 18.2: 181-191.

Aydın-Düzgit, Senem (2013). "European security and the accession of Turkey: Identity and foreign policy in the European Commission". Cooperation and Conflict 48.4: 522-541.

Baban, Feyzi and Fuat Keyman (2008). "Turkey and Postnational Europe Challenges for the Cosmopolitan Political Community". European Journal of Social Theory 11: 107-124.

Belder, Bas. "Progress report on enlargement". http:// www.europarl.europa.eu . (Accessed 04.10.2016).

Bizzotto, Mara. "Tensions between Turkey and the Republic of Cyprus". http://www.europarl.europa. eu. (Accessed 04.10.2016).

Blokker, Paul (2008). “Europe 'United in Diversity' From a Central European Identity to Post-Nationality?". European Journal of Social Theory 11.2: 257-274.

Brack, Natalie (2015). "The roles of Eurosceptic Members of the European Parliament and their implications for the EU". International Political Science Review, 36.3: 337-350.

Buckingham, Louisa (2013). "Mixed messages of solidarity in the Mediterranean: Turkey, the EU and the Spanish press". Discourse and Society 24.2: 186-207.

Camre, Mogens. "Progress towards accession by Turkey". http://www.europarl.europa.eu. (Accessed 24.09.2016).

Canan-Sokullu, Ebru Ş. (2011). "Turcoscepticism and Threat Perception: European Public and Elite Opinion on Turkey's Protracted EU Membership". South European Society and Politics 16.3: 483-497.
Cuisan, Catherine (2012). A Political Theory of Identity in European Integration: Memories and Policies. Oxon: Routledge.

Delanty, Gerard (1995). Inventing Europe: Idea, Identity, Reality. London: Palgrave Macmillan.

Delanty, Gerard (2002). "Models of European Identity: Reconciling Universalism and Particularism." Perspectives on European Politics and Society 3.3: 345359.

Delanty, Gerard and Chris Rumford (2005). Rethinking Europe: Social Theory and The Implications of Europeanization. Oxon: Routledge.

Diez, Thomas (2004)."Europe's Others and the Return of Geopolitics". Cambridge Review of International Affairs 17.2: 319-335.

Diez, Thomas (2005). "Constructing the Self and Changing Others: Reconsidering 'Normative Power of Europe'". Millenium-Journal of International Studies 33: 613-636.

Dryzek, John S. (1988). "The Mismeasure of Political Man". The Journal of Politics 50.3: 705-725.

Eder, Klaus (2006). “Europe's Borders: The Narrative Construction of the Boundaries of Europe". European Journal of Social Theory 9.2: 255-271.

Eder, Klaus (2009). "A Theory of Collective Identity Making Sense of the Debate on a 'European Identity".' European Journal of Social Theory 12.4: 427-447.

Europarl (2003). "The European Parliament in the Enlargement Process - An Overview". http://www. europarl.europa.eu/enlargement_new/positionep/ pdf/ep_role_en.pdf. (Accessed 03.01 2016).

European Communities (2009). “Building Parliament: 50 Years of European Parliament History". http://www. ab.gov.tr/files/ardb/evt/1_avrupa_birligi/1_1_tarihce/50_years_of_euroPean_parliament_history. pdf. (Accessed 07.01.2016).

European Council in Copenhagen. 21-22 June 1993. "Conclusions of the Presidency". Copenhagen. https://www.consilium.europa.eu/media/21225/72921.pdf . (Accessed 10.05.2019).

Grabbe, Heather and Nadja Groot (2014). “Populism in the European Parliament: What Implications for the Open Society?". The International Spectator, 49.4: 33-46.

Hall, Stuart (1992). "The West and Rest: Discourse and Power. Formations of Modernity". The Indigenous Experience: Global Perspectives. 165-173. 
Jałowiecki, Stanisław. "Preparation of the European Council". http://www.europarl.europa.eu (Accessed 10.10.2016).

Jupille, Joseph James et al. (2003). "Integrating institutions rationalism, constructivism, and the study of the European Union". Comparative Political Studies 36.1-2:7-40.

Kahraman, Sevilay (2012). "The Future of European Integration Process and Turkey". In Turkey's Accession to the European Union: Political and Economic Challenges, eds. Belgin Akçay and Bahri Yılmaz. 317-334. UK:Lexington.

Karatzaferis, Georgios. "Turkey's progress towards accession". http://www.europarl.europa.eu. (Accessed 09.09.2016).

Keyder, Çağlar (2006). "Moving in from the Margins? Turkey in Europe". Diogenes 53.2: 72-81.

Kösebalaban, Hasan (2007). "The permanent 'other'? Turkey and the question of European identity" Mediterranean Quarterly 18.4:87-111.

Kylstad, Ingrid (2010). "Turkey and the EU: A 'New'European Identity in the Making?". LSE 'Europe in Question' Discussion Paper Series, 27/2010, The London School of Economics and Political Science, London.

Lang, Carl. "Explanations of vote". http://www.europarl. europa.eu. (Accessed 09.09.2016).

Le Pen, Jean-Marie. “Voting time". http://www.europarl. europa.eu. (Accessed 09.09.2016).

Le Pen, Marine. "Explanations of vote." http://www. europarl.europa.eu. (Accessed 24.09.2016).

Le Rachinel, Fernand. "Explanations of vote." http:// www.europarl.europa.eu (Accessed 04.10.2016).

Mathieu, Véronique. "Progress towards accession by Turkey." http://www.europarl.europa.eu (Accessed 17.09.2016).

Matonytè, Irmina and Vaidas Morkevičius (2009). "Threat perception and European identity building: the case of elites in Belgium, Germany, Lithuania and Poland". Europe-Asia Studies 61.6: 967-985.

Melakopides, Costas (2000). "On the Mediterranean "Fuzzy Edge" of the EU: The Candidacies of Malta, Cyprus and Turkey". Journal of European Integration 22.3: 299-334.

Mikkeli, Heikki (1998). The Border of Defence: Europe and Russia. In Campling J. (eds) Europe as an Idea and an Identity. London:Palgrave Macmillan.

Morozov, Viatcheslav and Bahar Rumelili (2012). "The External Constitution of European Identity: Russia and Turkey as Europe-makers". Cooperation and Conflict 47.1: 28-48.

Murphy, Alexander (2005). "The Changing Geography of Europeanness". Geopolitics 10.3: 586-591.

Müftüler-Baç, Meltem (1998). "The never-ending story: Turkey and the European Union". Middle Eastern Studies 34.4: 240-258.

Müftüler-Baç, Meltem (2000). "Through the looking glass: Turkey in Europe". Turkish Studies 1.1: 21-35.

Müftüler-Baç, Meltem (2005). "Turkey's Political Reforms and the Impact of the European Union". South European Society and Politics 10.1: 6-30.

Negrine, Ralph (2008). "Imagining Turkey: British Press Coverage of Turkey's Bid for Accession to the European Union in 2004". Journalism 9.5: 624-645.

Neumann, Iver B. (1999). Uses of the Other: "The East" in European Identity Formation. Minnesota: Minnesota Press.

Öniş, Ziya (1999). "Turkey, Europe, and Paradoxes of Identity: Perspectives on the International Context of Democratization". Mediterranean Quarterly 10.3: 107-136.

Phillips, Nelson and Cynthia Hardy (2002). Discourse analysis: Investigating processes of social construction. Vol. 50. Sage.

Pistelli, Lapo.“Turkey's progress towards accession." http:// www.europarl.europa.eu. (Accessed 04.10.2016).

Rubington, Earl and Martin S. Weinberg (2003). The Study of Social Problems: Seven Perspectives. Social Constructionism. New York: Oxford University Press.

Rumelili, Bahar (2004). "Constructing Identity and Relating to Difference: Understanding the EU's Mode of Differentiation". Review of International Studies 30.1: 27-47.

Rumelili, Bahar (2008). “Negotiating Europe: EU-Turkey Relations from an Identity Perspective". Insight Turkey 10.1: 97-110.

Rumelili, Bahar (2011). “Turkey: Identity, Foreign Policy, and Socialization in a Post-Enlargement Europe". Journal of European Integration 33.2:235-249.

Rumford, Chris (2000). "From Luxembourg to Helsinki: Turkey, the Politics of EU Enlargement and Prospects for Accession". Contemporary Politics 6.4: 331-343.

Scheuer, Angelika and Hermann Schmitt (2009). "Dynamics in European Political Identity". Journal of European Integration. 31.5: 551-568.

Schlenker, Andrea (2013). "Cosmopolitan Europeans or Partisans of Fortress Europe? Supranational Identity Patterns in the EU". Global Society 27.1: 25-51. 
Spohn, Willfried (2009). "Europeanization, Religion and Collective Identities in an Enlarging Europe A Multiple Modernities Perspective". European Journal of Social Theory 12.3: 358-374.

Stråth, Bo (2002). "A European Identity to the Historical Limits of a Concept". European Journal of Social Theory 5.4: 387-401.

Tekin, Beyza Ç. (2010). Representations and othering in discourse: the construction of Turkey in the EU context. Amsterdam: John Benjamins.

Treaty Establishing a Constitution for Europe. 29.10.2004. Rome. https://europa.eu/europeanunion/sites/europaeu/files/docs/body/treaty_establishing_a_constitution_for_europe_en.pdf. (Accessed 10.05.2019).

Treaty on European Union. 07.02.1992. Maastricht. https://europa.eu/europeanunion/sites/europaeu/ files/docs/body/treaty_on_european_union_ en.pdf. (Accessed 10.05.2019).

van Dalen, Peter. "Enlargement strategy 2009." http:// www.europarl.europa.eu. (Accessed 09.09.2016). van Teeffelen, Toine (1994). "Racism and metaphor: The Palestinian-Israeli conflict in popular literature". Discourse \& Society 5.3: 381-405.

Weiler, Joseph H. (2007). "A Christian Europe? Europe and Christianity: Rules of Commitment". European View 6.1: 143-150.

Wetherell, Margaret et al. (2001). Discourse as data: $A$ guide for analysis. SAGE.

Wodak, Ruth (2001). Methods of Critical Discourse Analysis London: SAGE.

Yanık, Lerna K. (2009). "The Metamorphosis of Metaphors of Vision: 'Bridging' Turkey's Location, Role and Identity after the end of the Cold War". Geopolitics 14.3: 531-545.

Yılmaz, Hakan (2007). "Turkish Identity on the Road to the EU: Basic Elements of French and German Oppositional Discourses". Journal of Southern Europe and the Balkans Online 9.3: 293-305.

Zaleski, Zbigniew. "Opening of Negotiations with Turkey". http://www.europarl.europa.eu. (Accessed 6.10.2016). 